\title{
Nitrogen Fertilization and Use of Container-grown Maple Selections as Hosts by the Potato Leafhopper
}

\author{
Jo-Ann Bentz ${ }^{1}$ \\ U.S. National Arboretum, Floral and Nursery Plants Research Unit, U.S. Department of Agriculture, \\ Agricultural Research Service, 10300 Baltimore Avenue, BARC-West, Building 010A, Room 238, Beltsville, \\ MD 20705-2350

\begin{abstract}
Alden M. Townsend ${ }^{2}$
U.S. National Arboretum, Floral and Nursery Plants Research Unit, U.S. Department of Agriculture, Agricultural Research Service, 11601 Old Pond Drive, Glenn Dale, MD 20769
\end{abstract}

\begin{abstract}
ADDITIONAL INDEX WORDs. oviposition, nymphal survivorship, leaf macronutrients, leaf micronutrients, growth rate, Acer rubrum, Empoasca fabae, freeman maple, red maple
\end{abstract}

\begin{abstract}
The suitability of container-grown clones of red maple, Acer rubrum L., as a host to the potato leafhopper, Empoasca fabae Harris (Homoptera: Cicadellidae), under different fertilization regimes was determined, and compared to different freeman maple cultivars (A. $\times$ freemanii E. Murray). Three clonal selections of red maple (USNA numbers 56026, 59904, and 55410), and three freeman maple cultivars (55892 'Indian Summer', 67256 'Jeffersred' [trademark Autumn Blaze], and 55890 'Armstrong') were potted in 7.6-L containers, fertilized with either $0,3.3$, or $6.6 \mathrm{~g} /$ pot of calcium nitrate and used in experiments. When given a choice, female leafhoppers laid more eggs on leaves of red maple clone 56026 than on leaves of clone 59904, with oviposition linearly increasing on both clones with increases in the fertilization level applied to the trees. Yet, when female leafhoppers were confined to leaves using organza sleeve cages, oviposition increased linearly as fertilizer level increased, without a significant clonal effect. Oviposition did not differ among freeman maple cultivars, nor was it influenced by the fertilizer level applied to the freeman maple trees. Nymphs had the lowest odds of surviving to adulthood when reared on the freeman maple 'Jeffersred', but highest when reared on red maple 59904. Red maple 59904 had the fastest growth rate while red maple 55410 had the slowest. Leaf initiation and expansion in red maple 56026 was significantly slower than in the other selections. Leaf development of these three red maple clones was significantly accelerated by the application of fertilizer, regardless of level. The maple selections differed in their mean amounts of foliar macronutrients and micronutrients, which related to the fertilizer level applied to trees. Unfertilized trees had the highest $\mathrm{C}$ to $\mathrm{N}$ ratio, which decreased as fertilizer level applied to trees was increased. This study showed that fertilization improved the performance of the potato leafhopper on previously nonpreferred maple selections, and that the foliar nutrient content and $\mathrm{C}$ to $\mathrm{N}$ ratio could be used as indicators of tree susceptibility to insect attack under different growing conditions.
\end{abstract}

Red maple (Acer rubrum), a very popular shade tree and one of the most frequently planted in the landscape (Kielbaso, 1990; U.S. Dept. of Commerce, 1988), is used for its environmental adaptability, attractive form, colorful flowers and fruits, and red autumn foliage color (Townsend and McIntosh, 1993). About 55 distinct cultivars are available in the nursery industry (Sibley et al., 1998).

Traditionally, red maple trees have been field-grown. However, container production of red maple is becoming an increasingly popular trend, following demands of the horticulture industry (Sibley et al., 1998). Most attention has been paid to the survival and improved growth of container-grown trees (Beeson, 1992; Larimer and Struve, 2002; Pham et al., 1978; Ponder et al., 1984; Sibley et al., 1998; Sibley and Ruter, 1999; Still et al., 1981). Yet, the suitability of container-grown maples as hosts to the potato leafhopper, Empoasca fabae Harris (Homoptera: Cicadellidae), has not been determined. This polyphagous insect is a serious problem on red maple, causing severe economic damage in nurseries and landscape settings (Potter and Spicer, 1993). Feeding by nymphs and adults on new maple shoots and leaf growth results in death

Received for publication 30 Dec. 2002. Accepted for publication 15 June 2003. We thank Amy Barbosa, Clara Fuentes, Nikhil Mallampalli, Stephen Mathers and Chris Scovitch, for their assistance with experiments (USDA-ARS-USNA, FNPRU), and to Lidia Carrera (USDA-ARS), for comments on the manuscript. Mention of a proprietary product does not constitute an endorsement or a recommendation by the USDA for its use.

${ }^{1}$ Research entomologist.

${ }^{2}$ Research geneticist. of apical tissue, deformed and necrotic leaves, and stunted shoots (Bentz and Townsend, 1997, 1999; Townsend, 1989).

We have previously shown that feeding injury and performance of the potato leafhopper on field-grown maple trees are related to leaf phenology and to the leaf nutrient content, and that these vary among maple clonal selections and cultivars (Bentz and Townsend, 1997, 1999, 2001). Yet, data are lacking on how these would differ for container-grown maple. Moreover, if leafhoppers are responding to the mineral content of their host, it is probable that interactions between maple hosts and this insect could be mediated through the use of fertilizers, which are routinely applied under production, as reported for other species (Kitchen et al., 1990; Roltsch and Gage, 1990; Shaw et al., 1986; Vough et al., 1992).

Thus, this study aimed to determine if nitrogen fertilization influences oviposition, survival and development of the potato leafhopper among container-grown maple selections, and if $\mathrm{N}$ fertilization influences the foliar element content, the $\mathrm{C}$ to $\mathrm{N}$ ratio, degree of flushing, tree height and percent growth rate of container-grown maple selections. Also, the suitability of red maples as hosts was compared to that of freeman maples $(A$. $\times$ freemanii E. Murray), which are crosses between red and silver maples ( $A$. saccharinum L.).

\section{Materials and Methods}

INSECT COLONY. A laboratory colony of the potato leafhopper was started in Spring 1994. Yearly thereafter, adults were col- 
lected in a potato field at the Beltsville Agricultural Research Center (BARC), Agricultural Research Service, U.S. Department of Agriculture (ARS-USDA), Beltsville, Md., and released into the colony. Insects were reared on a mixture of Henderson's bush lima bean (Phaseolus lunatus L.) and fava bean (Vicia faba L.) kept in clear plastic cages $(60 \times 60 \times 30 \mathrm{~cm}$, or $60 \times 60 \times 60 \mathrm{~cm})$. Cages were maintained in a walk-in environmental chamber set at $25.5{ }^{\circ} \mathrm{C}, 60 \%$ to $80 \%$ relative humidity and a photoperiod of 16 : 8 light:dark (L:D) h.

TREES. Ramets of three USDA, U.S. National Arboretum(USNA) clonal selections of red maples (USNA numbers 56026, 59904, and 55410), and three freeman maple cultivars (55892 'Indian Summer', 67256 'Jeffersred' [trademark Autumn Blaze], and 55890 'Armstrong') were potted in 7.6 L containers, using a potting mix of 50:50 Peat:Perlite, in either 1993 or 1994, at the USDA-ARS station near Glenn Dale, Md. These potted trees were transferred to BARC on 31 Jan. 1994. The potted trees received a one time micronutrient drench [Peter's Soluble Trace Element Mixture (STEM)] in the spring, at half the recommended rate. Trees were grown in a research greenhouse, at $30 \pm 5^{\circ} \mathrm{C}$, in a photoperiod of 16:8 (L:D) h, and following standard maintenance nursery practices. Humidity was not controlled. At the onset of dormancy, about the second week of December, trees were moved into a cold frame outside the greenhouse, and covered with plastic sheeting. During the first week of March, trees were uncovered and transferred back into the greenhouse.

Fertilization treatments. Fertilization was started on $14 \mathrm{Feb}$. 1994, shortly after the potted trees were received at BARC. Trees from each clonal selection were divided into three groups, and treatments assigned. Treatments consisted of tap water as a control, i.e., $0 \mathrm{~g}$, and of 3.3 or $6.6 \mathrm{~g} /$ pot solutions of calcium nitrate $\left(\mathrm{Ca}\left(\mathrm{NO}_{3}\right)_{2}\right.$, $15.5 \%$ total nitrogen) (Brighton ByProducts, New Brighton, Pa.). Weekly, each pot received $1000 \mathrm{~mL}$ of fertilizer solution or water that thoroughly wetted the media to container capacity with no net loss. Yearly fertilization was started when the first buds were noted to enlarge, and continued until most leaves were fully expanded, lasting $\approx 10$ weeks. Trees were watered as needed.

OVIPOSITION CHOICE TEST USING CONTAINER-GROWN TREES, 1995. Four potted trees from each fertilizer level of red maple selections 56026,59904, and 55410 were randomly chosen from those growing in the greenhouse and transferred into two walk-in environmental chambers set at $25.5^{\circ} \mathrm{C}, 60 \%$ to $80 \%$ relative humidity and a photoperiod of 16:8 (L:D) h. Within the chambers, trees were divided into two groups. Each group contained one tree from each maple selection by fertilizer level combination for a total of nine trees per group. Each group was then covered with a white organza sleeve $(153 \times 153 \mathrm{~cm})$. The sleeve was sewn on three sides resembling a pillow case to enclose the trees, and taped to the floor using masking tape. Bamboo sticks were used to keep the fabric away from the leaves. Potato leafhopper females were collected from the laboratory colony using an insect aspirator, and then released into the sleeve cages. A total of 50 females were released per cage. Females were allowed to oviposit for $4 \mathrm{~d}$. At this time, all the leaves were collected from each tree, placed in a plastic bag, and stored in the freezer at $-20^{\circ} \mathrm{C}$. Later, potato leafhopper eggs were stained within leaves as described in Bentz and Townsend (1999), and then searched for and counted with the aid of a stereomicroscope. The experiment was repeated twice, on 5 and 19 May 1995, using new trees each time. The freeman maple cultivars were not included in these tests as preliminary data showed that oviposition did not occur on these trees.

Oviposition No-CHOICE TEST, 1995. Potted trees from each fertilizer level of red maple selections 56026, 59904, and 55410 were taken from the greenhouse and brought to the laboratory. In the laboratory, leaves were cut off from the trees, singly put into $250-\mathrm{mL}$ flasks with the petioles immersed in tap water, and secured in place using cotton and parafilm. Each leaf was loosely covered with an organza sleeve $(30.5 \times 38 \mathrm{~cm})$, tied around the flask's mouth. Flask sleeves were placed on trays and kept in an environmental walk-in chamber set as before. Potato leafhopper females, $\approx 1$ week old, were collected in groups of five from the laboratory colony and released into the sleeves. Females were allowed to oviposit for $6 \mathrm{~d}$, after which they were removed. The leaves exposed to the females were collected singly, and stained as described above. Eggs within leaf tissues were searched with the aid of a stereomicroscope and counted. Eight flasks with leaves were used per maple selection by fertilizer level combination for a total of 72 flasks per trial. The test was repeated twice, on 16 June and on 20 July 1995. The freeman maple cultivars were not included in these tests as preliminary data showed that oviposition did not occur on detached leaves.

OVIPOSITION NO-CHOICE TEST USING CONTAINER-GROWN TREES IN THE GREENHOUSE, 1999. Potted trees of red maple selections 56026, 59904, 55410, and of freeman maples 'Jeffersred', 'Armstrong', and 'Indian Summer' that had been fertilized with the assigned fertilizer level were transferred into a research greenhouse. One branch on each of three trees per maple selection by fertilizer level combination was tagged. Then, tagged branches were enclosed using organza sleeves as described above. Potato leafhopper females were collected from the laboratory colony in groups of five and released into the organza sleeves enclosing the tagged branches (one group of five females per organza sleeve cage). Females were allowed to oviposit for $6 \mathrm{~d}$. At this time, sleeve cages enclosing the branches with leaves were cut off the trees, brought to the laboratory and stored in a freezer at $-20{ }^{\circ} \mathrm{C}$ to kill the ovipositing females. The leaves within sleeve cages were collected, and stained as described above. Eggs within leaf tissues were searched for and counted as described above. The test was repeated seven times between June and August 1999.

NYMPHAL EMERGENCE ON CONTAINER-GROWN RED MAPLE SELECTIONS. Potted trees of red maple selections 56026, 59904, and 55410 from each fertilizer level were transferred into each of four walkin environmental chambers set at $25.5{ }^{\circ} \mathrm{C}, 60 \%$ to $80 \%$ relative humidity, and a photoperiod of 16:8 (L:D) h. Thus, each chamber contained nine trees; one tree of each maple selection by fertilizer level combination. A group of 100 female leafhoppers, collected from the leafhopper colony, was released into each chamber. On the fourth day after release, leafhoppers were collected from the trees, and each tree was covered individually using an organza sleeve sewn as a pillow case $(122 \times 92 \mathrm{~cm})$. Leaves were collected from each tree $15 \mathrm{~d}$ later. Nymphs found on leaves were counted. The experiment was started on 12 June 1997.

NyMPHAL SURVIVAL TO ADULTHOOD ON CONTAINER-GROWN MAPLE SELECTIONS IN THE GREENHOUSE. Potted trees of red maple selections 56026, 59904, 55410, and of freeman maples 'Jeffersred', 'Armstrong', and 'Indian Summer', that had been fertilized with the assigned fertilizer level, were transferred into a research greenhouse. Three trees per maple selection by fertilizer level combination were used in the experiment, for a total of 54 trees. One branch on each tree was tagged. Second instars were collected from the laboratory colony in groups of two, and released into organza sleeve cages enclosing the tagged branches (one group of two nymphs per organza sleeve cage). Nymphs were checked daily until becoming adults. At this time, cages enclosing the branches with leaves were 
cut off the trees, brought to the laboratory, and stored in a freezer at $-20{ }^{\circ} \mathrm{C}$ to kill the leafhoppers. Then, the number of adults was counted. The experiment was repeated on 29 June 1999, 7 July, 1999, 13 July 1999, 25 July 1999, 28 June 2000, 12 July 2000, and 26 July 2000.

Percent growth Rate AND LEAF DeVelopment of CONTAinerGROWN RED MAPLE SELECTIONS. Ten trees of red maple clones 56026, 59904, and of 55410 from each fertilizer level were selected to be measured. Tree height was measured on 16 Mar. 1995 (trees removed from cold frame on 2 Mar. 1995), and on 18 Mar. 1997 (trees removed from cold frame on 4 Mar. 1997), as the distance between the potting soil level to the tip of the central leader. The percent growth rate was calculated for each tree as [(height in 1997 - height in 1995)/height in 1995] × 100. Degree of flushing, or leaf development, was visually assessed on 22 Mar. 1995, 21 Mar. 1997, and on 23 Mar. 1998 (trees removed from cold frame on 3 Mar. 1998), $\approx 19 \mathrm{~d}$ after moving the trees into the greenhouse, and indexed with 0 signifying no signs of budbreak and leaf development, 3 signifying that $\approx 30 \%$ of the tree was showing swollen buds, 5 signifying that $\approx 50 \%$ of the tree was showing elongated buds or newly opened leaves, 7 signifying that $\approx 70 \%$ of the tree was showing newly opened or young leaves, and 10 signifying that $\approx 90 \%$ of the leaves on a given tree were showing full leaf expansion.

Elemental analyses of Foliage and C to N RATio OF CONTAINER-GROWN RED MAPLE AND FREEMAN MAPLE. Three trees per maple selection by fertilizer level combination were tagged to be used for these determinations. Leaf samples were collected by randomly cutting two shoots from each tree on 19 June, 25 June, 9 July, and 13 July 1999. Shoots were brought to the laboratory where the leaves with the petioles attached were removed, pooled, weighed fresh, and stored at $-20{ }^{\circ} \mathrm{C}$ in the freezer until analysis. Samples were pooled by month, and those weighing at least 10 $\mathrm{g}$ fresh weight were submitted to a commercial analytical laboratory for element content determination (Brookside Laboratories, Inc., New Knoxville, Ohio). Samples were digested in a nitric acid /hydrogen peroxide microwave digestion system (model 2100; CEM-MDS, Matthews, N.C.). All elements, except nitrogen, were analyzed using an inductively coupled plasma spectrometer (ICP) (model 61E; Thermo Jarrell Ash 61E, Waltham, Mass.). Total N and $\mathrm{C}$ were determined using a Carlo Erba N-C-S analyzer (model NA 1500; Milan, Italy).

STATISTICAL ANALYSES. Oviposition and nymphal emergence data were coded by adding a 1 to avoid deleting observations with zero values and then $\log _{10}$ transformed to correct for lack of homogeneity of variances. Data were analyzed using regression techniques with maple selection coded as a dummy variable. Data from the nymphal survival experiment were analyzed using the logistic regression procedure within SAS (SAS Institute, 1999) for binary data. Nymphal survivorship was scored as 0 if both nymphs were dead, or as 1 if at least one nymph within the cage became an adult. Logistic regression was performed to test for coincidence and parallelism of the slopes and for generating parameter estimates for the logistic regression equation.

The tree percent growth rate data were analyzed using regression techniques with maple selection coded as a dummy variable. The leaf development data were analyzed using the generalized linear model procedure within SAS (SAS Institute, 1999), with multinomial distribution and cumulative logit link function, and fertilizer level and maple selection treated as main effects. The year when experiments were repeated was included as a block effect. The nutritional element data and the $\mathrm{C}$ to $\mathrm{N}$ ratio data were analyzed using a two-way analysis ANOVA, with maple selection and fertilizer level treated as main effects. Month when the sample was collected was included as a covariate in the analysis. The linear and quadratic effects were tested using orthogonal polynomial contrasts. For all data, means and standard errors were generated using the MEANS or LSMEANS statement within SAS (SAS Institute, 1999). Means were compared using contrasts at $P=0.05$.

\section{Results and Discussion}

Oviposition tests. Dissection of leaves from the choice test revealed that no eggs were laid in leaves of red maple 55410. Although oviposition on red maple 56026 and 59904 increased linearly with increases in the fertilization level applied to the trees, their regression slopes were significantly different (test of coincidence: $\mathrm{F}=15.64, P=0.0433$; test of parallelism: $\mathrm{F}=31.21$, $P=0.0306$ ) (Fig. 1A). While no eggs were found on trees of red maple 59904 that were not fertilized, oviposition increased at a faster rate on fertilized trees of red maple 59904 than on 56026. Yet when female leafhoppers were confined to single leaves in the no-choice test, oviposition increased linearly as fertilizer level increased, over all red maple clones ( $\mathrm{F}=8.08 ; P=0.0052)$ (Fig. 1B). Regression coefficients did not differ among the red maples (test of coincidence: $\mathrm{F}=1.04, P=0.5073$; test of parallelism: $\mathrm{F}$ $=0.76, P=0.5395)$.

Oviposition was significantly different among freeman maple and red maple selections tested in the greenhouse (Fig. 1C). Oviposition

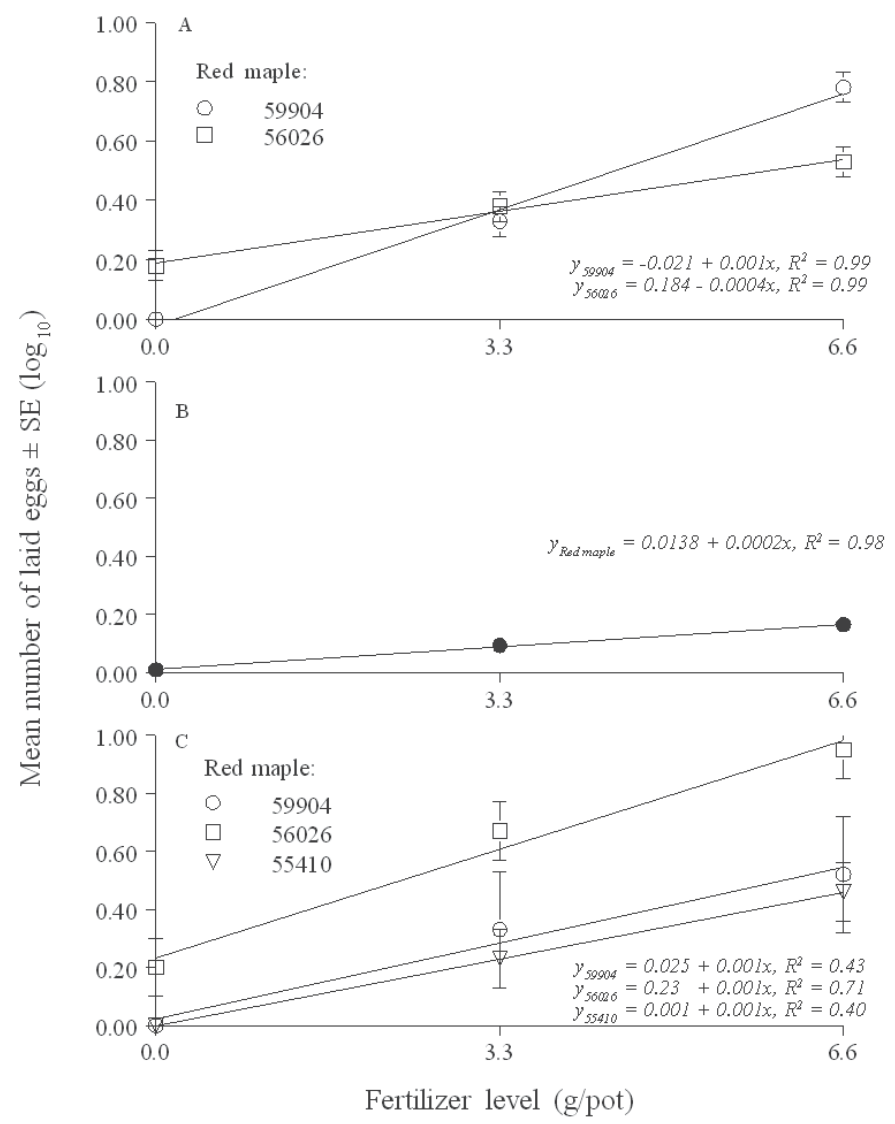

Fig. 1. Effect of fertilizer level on the number of eggs laid per tree by potato leafhopper females among red maple selections. (A) Oviposition choice test using potted trees in environmental chambers, 1995. (B) Oviposition no-choice test among selections using detached leaves, 1995. (C) Oviposition no-choice test using potted trees in the greenhouse, 1999 . Vertical bars represent \pm SE. Lines represent the fitted regression slope. Overall means for the freeman maples: $\overline{\mathrm{x}}_{\text {Jefferssed }}=0.17 \pm 0.10 ; \overline{\mathrm{x}}_{\text {Armstrong }}=0.18 \pm 0.10 ; \overline{\mathrm{X}}_{\text {Indian Summer }}=0.16 \pm 0.10$. 
by female leafhoppers confined to red maple leaves increased as fertilizer level increased $(\mathrm{F}=28.66 ; P<0.0001)$. Although regression slopes were not different, and thus were parallel, regression intercepts were different among the red maple clones, so slopes did not coincide (test of coincidence: $\mathrm{F}=3.92, P=0.0185$; test of parallelism: $\mathrm{F}=0.63, P=0.5457)$. Oviposition did not differ among freeman maple cultivars, and was not significantly influenced by fertilizer level (test of coincidence: $\mathrm{F}=0.84, P=0.5204$; test of parallelism: $\mathrm{F}=1.65, P=0.2202)$.

These results parallel what we have observed to occur with field grown trees (Bentz and Townsend, 1999). Oviposition was significantly higher on field grown trees of red maple 56026 than on 55410, and it was significantly lower on freeman maple than on red maple. We have not been able to determine if nonpreference of the freeman maple by the potato leafhopper is caused by the presence of allelochemicals, as it does not appear to be morphologically related (Bentz and Townsend, 1999). Because ovipositing female leafhoppers were confined to individual shoots, they probably laid eggs according to the nutritional suitability of the leaves (Carlson and Hibbs, 1970). Increased oviposition with increases in the level of fertilizer applied to maple trees is consistent with reported findings of higher oviposition in beans containing the greatest amount of total nitrogen when grown under different fertilizer levels (Roltsch and Gage, 1990).

Nymphal EMERgenCE AND SURVival to AdUlthood. Nymphal emergence among the red maple selections was significantly influenced by fertilizer level, with regression slopes differing among selections (test of coincidence: $\mathrm{F}=2386.34, P<0.0001$; test of parallelism: $\mathrm{F}=253.60, P=0.0005$ ) (Fig. 2). While the number of nymphs reared on red maple clones 59904 and 56026 increased linearly with increases in the fertilizer level, this number decreased on red maple 55410 with increases in fertilizer level. Significantly more nymphs emerged on red maple 56026 than on the others.

Nymphal survivorship to adulthood among the different maple selections was influenced by fertilization level, with significant differences among the slopes of the six different selections (test of coincidence: Wald- $\chi 5=74.243, P<0.0001$; test of parallelism: Wald $-\chi 5=23.88, \mathrm{P}=0.00005$ ) (Fig. 3). Nymphs had the lowest odds of surviving to adulthood when reared on 'Jeffersred', but highest when reared on red maple 59904. A quadratic response was significant for red maple 55410 and 'Armstrong', yet these differed

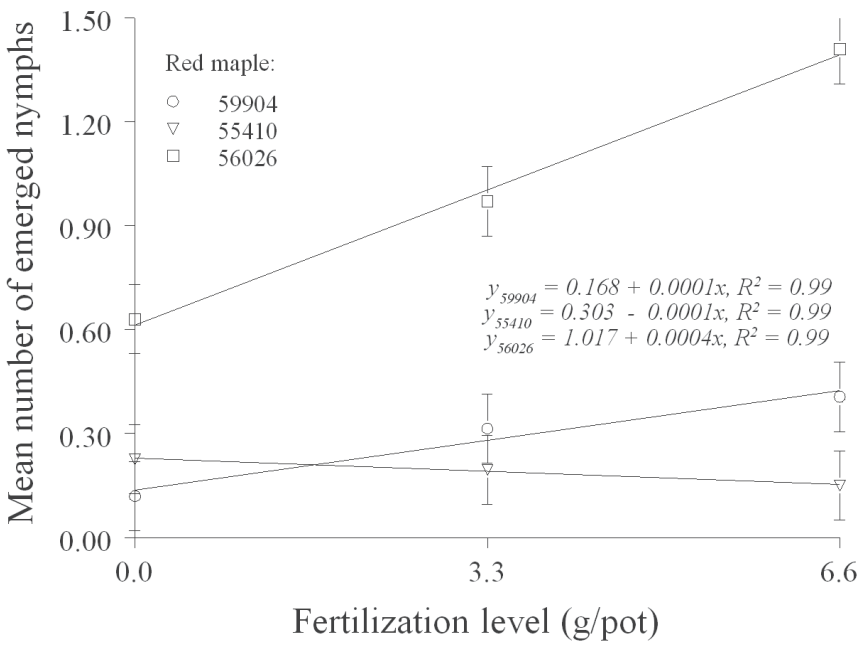

Fig. 2. Effect of fertilizer level on the number of emerged nymphs per tree among red maple selections. Vertical bars represent \pm SE. Lines represent the fitted regression slope. in the direction of their response. Survivorship on the other selections linearly increased as fertilization level was increased.

Differences in nymphal survivorship among the different clones in the present study appear to be influenced directly by the host tree. Lower leafhopper survivorship on selections such as 55410 and 'Jeffersred' may be due, in part, to nutritional limitations or to the decreasing availability of suitable feeding sites for nymphal growth and development. The quantity or quality of an allelochemical or a primary metabolite may have been influenced by increases in the $\mathrm{N}$ content in those trees where nymphs suffered higher mortality. Changes in nutrition that influence fecundity or survival of adults and survival or development of progeny, affecting the expression of antibiosis have been shown with many other insects (Cannon and Ortega, 1966; Kindler and Staples, 1970).

Percent Tree growth Rate AND Leaf DeVelopment. The mean percent growth rate was significantly influenced by the interactive effect of maple selection and fertilizer level; regression slopes were significantly different among selections (test of coincidence: $\mathrm{F}=$ 53.24, $P=0.0041$; test of parallelism: $\mathrm{F}=48.84, P=0.0051)$. The mean percent growth rate of maple selections increased linearly with increases in the fertilizer level applied to the trees (Fig. 4). Red maple 59904 had the highest growth rate while red maple 55410 had the slowest rate. Other studies have shown that fertilization at tree planting has no effect on top growth (Kelting et al., 1998; Shoup et al., 1981; Shulte and Whitcomb, 1975; Smalley and Wood, 1995; Van de Werken, 1981), while Hensley et al. (1988) found an increase of top growth for container-grown Magnolia grandiflora L.

Leaf development was significantly influenced by the interactive effect of maple clone and fertilizer level $(\chi 5=40.94 ; P<0.0001)$ (Fig. 5). Red maple 56026 foliage developed significantly slower than the other selections. Leaf development of these three maple clones was significantly accelerated by the application of fertilizer, regardless of level. The results obtained from the trees that were not fertilized are the same as previous reported findings for field grown trees (Bentz and Townsend 1997). As with field trees, clone 55410 was the first clone to show signs of leaf flushing. The order of leaf flushing from early to late was 55410 with more leaves than 59904, which in turn had more leaves than 56026. Full leaf flushing of clone 56026 occurred later in the spring.

Foliar NUTRIENTS. The mean amount of each foliar nutrient

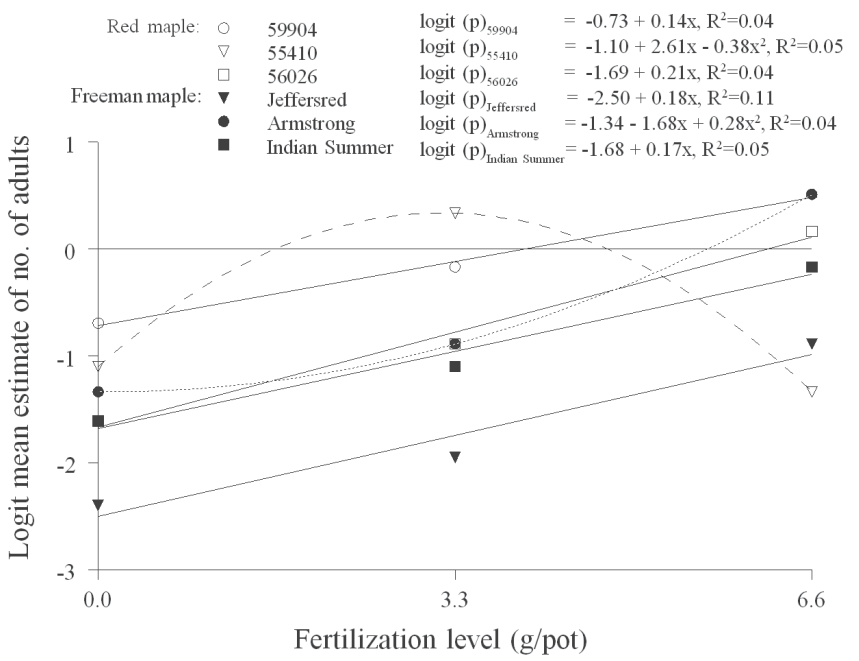

Fig. 3. Effect of fertilizer level on nymphal survivorship to adulthood among different red maple and freeman maple selections. Vertical bars represent \pm $\mathrm{SE}$. Lines represent the fitted regression slope. The max-rescaled $R^{2}$ value is presented (SAS Institute, 1999). 


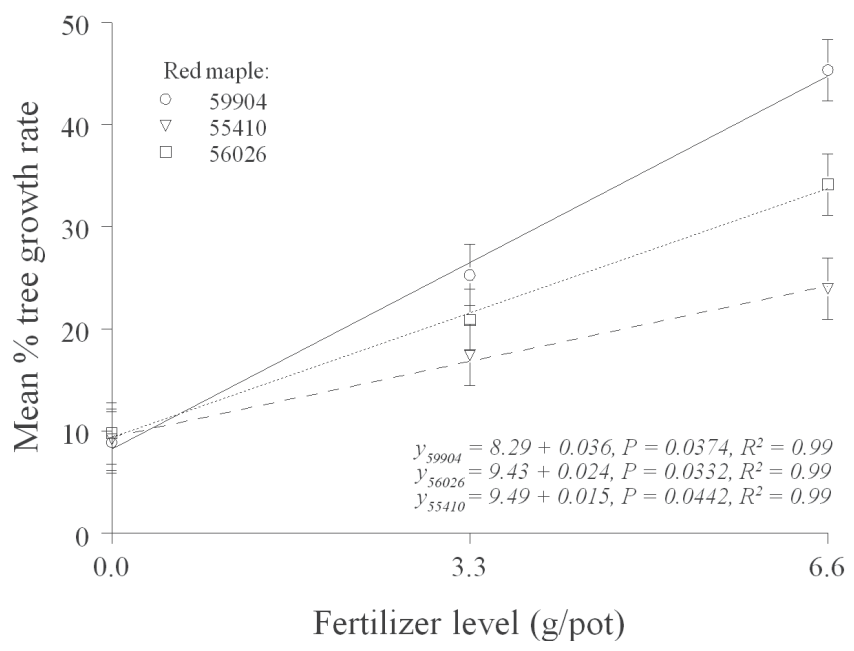

Fig. 4. Effect of fertilizer on the percent growth rate of red maple selections. Vertical bars represent \pm SE. Lines represent the fitted regression slope.

was not influenced by the interactive effect of maple selection and fertilizer level. Yet, these nutrients were significantly influenced by fertilizer level or maple selection as a main effect (Table 1). While the mean amounts of $\mathrm{N}, \mathrm{P}, \mathrm{K}, \mathrm{Ca}, \mathrm{S}$, and Fe increased linearly as fertilizer level increased, the mean amounts of $\mathrm{Mg}$ and $\mathrm{B}$ decreased linearly with increases in the fertilizer level.

The mean amounts of N, P, Ca, S, B, Mn, Cu, Zn, and Al were significantly influenced by maple selection as a main effect. The freeman maples 'Jeffersred' and 'Indian Summer' had more N than the other selections. 'Jeffersred' contained more P than the other selections, but 'Indian Summer' contained the least. Red maple 59904 contained less Ca than the other selections. Red maple selections did not differ in their mean S content. Yet, 'Jeffersred' and 'Armstrong' maples contained more S, while 'Indian Summer' contained less S than the other selections. 'Armstrong'

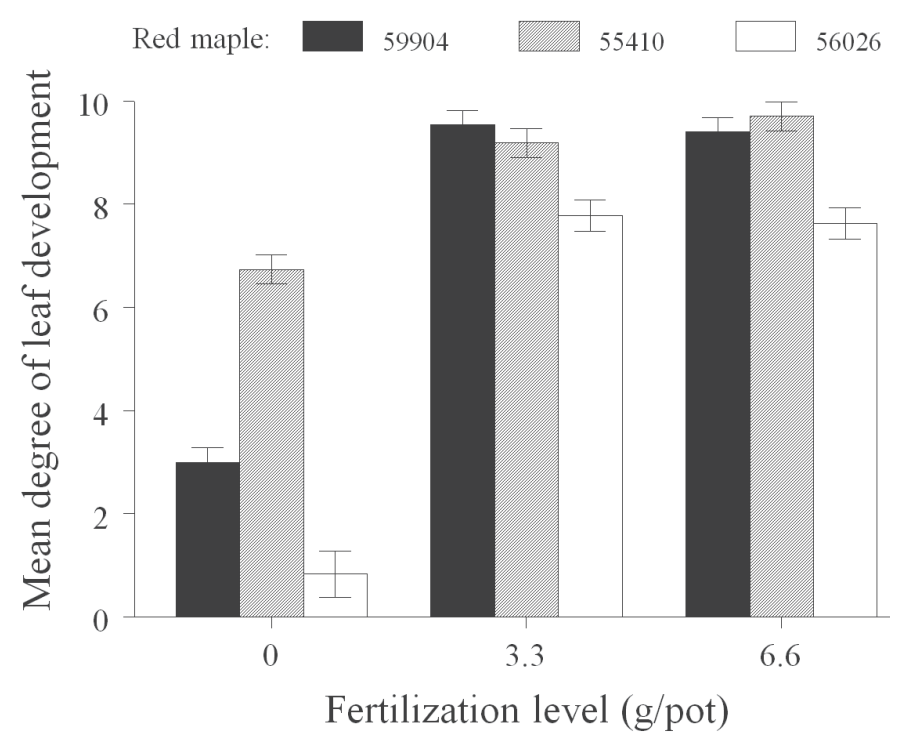

Fig. 5. Effect of fertilizer level on leaf development of red maple selections assessed $\approx 19 \mathrm{~d}$ after trees were moved into the greenhouse. Vertical bars represent \pm SE. Degree of leaf development was indexed as 0 signifying no signs of budbreak, 3 signifying that $\approx 30 \%$ of the tree was showing swollen buds, 5 signifying that $\approx 50 \%$ of the tree was showing elongated buds or newly opened leaves, 7 signifying that $\approx 70 \%$ of the tree had newly opened or young leaves, and 10 signifying that $\approx 90 \%$ of the leaves on a given tree were showing full leaf expansion. maples contained more B than the other selections. Red maple 55410 contained less $\mathrm{Mn}$ than the others. Red maple 55410 and 'Indian Summer' maple contained less $\mathrm{Cu}$ than the other selections. Red maple 56026, 'Jeffersred', and 'Armstrong' contained more $\mathrm{Zn}$ than the other maples. Red maple 59904 contained less Al than the other selections.

Variations in the foliar concentrations may be coupled with genotypic differences in nutrient uptake, utilization and translocation, and tree phenology, thus making it difficult to compare with values published by others (Chandler, 1941; Gordon et al., 1989; McCormick, 1997; Sibley et al., 1996). Pham et al. (1978) noted that growth of red maple seedlings was maximum when available soil $\mathrm{N}$ was $25 \mathrm{ppm}, \mathrm{P}$ was 25 to $75 \mathrm{ppm}$, and K was 75 to 100 ppm. Gilliam et al. (1980) found that container grown 'Red Sunset' maple that had been fertilized with 300 ppm $\mathrm{N}$ contained higher $\mathrm{N}$ concentrations in both mature and immature leaves, as compared to trees fertilized with $50 \mathrm{ppm} \mathrm{N}$. In the present study, fertilization-induced changes in the concentration of foliar elements may act indirectly on the potato leafhopper by altering the nutritional quality of the tree, i.e., $\mathrm{N}$ content, thus influencing acceptability of the host tree for oviposition, and survival and development, as we have previously shown (Bentz and Townsend, 1999, 2001).

$\mathrm{C}$ to $\mathbf{N}$ Ratio. The $\mathrm{C}$ to $\mathrm{N}$ ratio was not influenced by the interactive effect of maple selection by fertilizer level $(\mathrm{F}=0.69$; $\mathrm{df}=10,18 ; P=0.7175)$ nor by maple selection $(\mathrm{F}=0.95 ; \mathrm{df}=5$, $18 ; P=0.4739$ ) as a main effect (Fig. 6). Yet, it was significantly influenced in a quadratic manner by fertilizer level as a main effect (F= 58.30; df = 2, 18; $\left.P=0.0005 ; R^{2}=0.92\right)$.

The $\mathrm{C}$ to $\mathrm{N}$ ratio has been used as an indicator of tree susceptibility to insect attack under different growing conditions. Bryant et al. (1983) speculated that plants provided with adequate light, but subjected to suboptimal nutrient availability, should exhibit a high $\mathrm{C}$ to $\mathrm{N}$ ratio and resistance to herbivory. The surplus $\mathrm{C}$ would result in accumulation of carbon-based secondary substances that defend the plants against herbivory. Although the $\mathrm{C}$ to $\mathrm{N}$ ratio was significantly higher for unfertilized trees, it was not determined in this study if these trees contained a higher content of carbon-based defenses such as tannins or phenolic compounds, perhaps explaining the low utilization of these trees by the potato leafhopper. The high $\mathrm{C}$ to $\mathrm{N}$ ratio of unfertilized trees indicate that these trees were nutrient limited and, thus, nonpreferred by the leafhoppers. Decreasing this ratio with increases in fertilization level indicates higher susceptibility to leafhopper feeding. It appears that nutrients

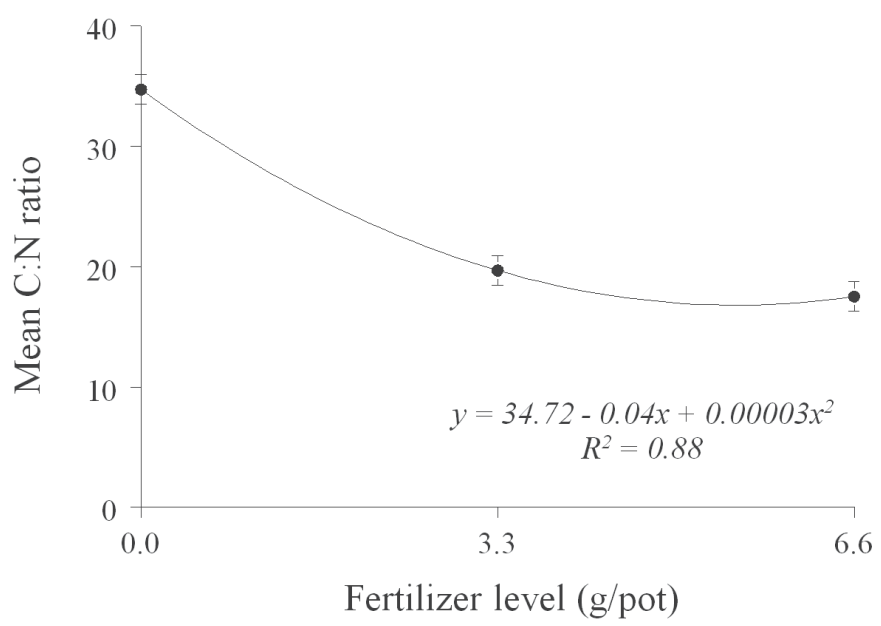

Fig. 6. Effect of fertilizer level on the mean $\mathrm{C}$ to $\mathrm{N}$ ratio. Vertical bars represent \pm SE. Lines represent the fitted regression slope. 
and non-nutritive compounds become more readily available to the insects infesting these trees.

\section{Conclusions}

Little is known about the susceptibility of container-grown trees to insect pests. As container production becomes more popular in the production of nursery trees, more attention should be paid to cultural practices, such as water and fertilizer usage. These practices improve the growth and development of the trees, but also influence the resistance or susceptibility against insect pests. For example, if resistance against the potato leafhopper could be induced by forcing budbreak or leaf maturity to occur earlier in the season, thus decreasing the availability of suitable leaves by the time of leafhopper arrival, a strategy could be developed to suppress population numbers and the feeding injury that it causes, decreasing reliance on insecticide usage for pest control.

This study corroborated our previous findings that red maple clones and freeman maple cultivars differed in their suitability to the potato leafhopper (Bentz and Townsend, 1999). Fertilization improved growth and leaf development of red maple trees. Yet, it also improved insect fitness on a previously nonpreferred red maple selection, i.e., red maple clone 55410. Also, fertilization improved the odds of leafhoppers surviving to adulthood on freeman maple cultivars and thus facilitating increases in population numbers. This study shows that care should be taken when adapting standard procedures in the production of container-grown trees, as these may aggravate previously insignificant pest problems.

\section{Literature Cited}

Beeson, Jr., R.C. 1992. Shoot and root responses of eighteen southeastern woody landscape species grown in cupric hydroxide-treated containers. J. Environ. Hort. 10:214-217.

Bentz, J. and A.M. Townsend. 1997. Variation in adult populations of the potato leafhopper (Homoptera: Cicadellidae) and feeding injury among clones of red maple. Environ. Entomol. 26:1091-1095.

Bentz, J. and A.M. Townsend. 1999. Feeding injury, oviposition, and nymphal survivorship of the potato leafhopper on red maple and freeman maple clones. Environ. Entomol. 28:456-460.

Bentz, J. and A.M. Townsend. 2001. Leaf element content and utilization of maple and elm as hosts by the potato leafhopper (Homoptera: Cicadellidae). Environ. Entomol. 30:533-539.

Bryant, J.P.,F.S. Chapin, III, and D.R. Klein. 1983. Carbon/nutrient balance of boreal plants in relation to vertebrate herbivory. Oikos 40:357-368.

Cannon, Jr., W.N. and A. Ortega. 1966. Studies of Ostrinia nubilalis larvae (Lepidoptera: Pyraustidae) on corn plants supplied with various amounts of nitrogen and phosphorus. I. Survival. Ann. Entomol. Soc. Amer. 59:631-638.

Carlson, O.V. and E.T. Hibbs. 1970. Oviposition by Empoasca fabae (Homoptera: Cicadellidae). Ann. Entomol. Soc. Amer. 63:516-519.

Chandler, Jr., R.F. 1941. The amount and mineral nutrient content of freshly fallen leaf litter in the hardwood forests of central New York. J. Amer. Soc. Agron. 33:859-871.

Gilliam, C.H., S.M. Still, S. Moor, and M.E. Watson. 1980. Effects of three nitrogen levels on container-grown Acer rubrum. HortScience 15:641-642.

Gordon, A.M., R.A. McBride, A.J. Fisken, and T.E. Bates. 1989. Effect of landfill leachate irrigation on red maple (Acer rubrum L.) and sugar maple (Acer saccharum Marsh.) Seedling growth and on foliar nutrient concentrations. Environ. Pollut. 56:327-336.

Hensley, D.L., R.E. McNeil, and R. Sundhem. 1988. Management influences on growth of transplanted Magnolia grandiflora. J. Arboricult. 14:204-207.
Kelting, M., J.R. Harris, J.Fanelli, and B. Appleton. 1998. Biostimulants and soil amendments affect two-year posttransplant growth of red maple and washington hawthorn. HortScience 33:819-822.

Kielbaso, J. 1990. Trends and issues in city forests. J. Arboricult. 16: 69-76.

Kindler, S.D. and R. Staples. 1970. Nutrients and the reaction of two alfalfa clones to the spotted alfalfa aphid. J. Econ. Entomol. 63:938-940.

Kitchen, N.R., D.D. Buchholz, and C.J. Nelson. 1990. Potassium fertilizer and potato leafhopper effects on alfalfa growth. Agron. J. 82: $1069-1074$.

Larimer, J. and D. Struve. 2002. Growth, dry weight and nitrogen distribution of red oak and 'Autumn Flame' red maple under different fertility levels. J. Environ. Hort. 20:28-35.

McCormick, L.H. 1997. Variation in mineral content of red maple sap across an atmospheric deposition gradient. Commun. Soil Sci. Plant Anal. 28:365-379.

Pham, C.H., H.G. Halverson, and G.M. Heisler. 1978. Red maple (Acer rubrum L.) growth and foliar nutrient responses to soil fertility level and water regime. USDA For. Serv. Res. Paper NE-412.

Ponder, H.G., C.H. Gilliam, E. Wilkinson, J. Eason, and C.E. Evans. 1984. Influence of trickle irrigation and nitrogen rates to Acer rubrum L. J. Environ. Hort. 2:40-43.

Potter, D.A. and P.G. Spicer. 1993. Seasonal phenology, management, and host preferences of potato leafhopper on nursery-grown maples. J. Environ. Hort. 11:101.

Roltsch, W.J. and S.H. Gage. 1990. Influence of bean-tomato intercropping on population dynamics of the potato leafhopper (Homoptera: Cicadellidae). Environ. Entomol. 19:534-543.

SAS Institute. 1999. SAS user's guide: Statistics. SAS Institute, Cary, N.C.

Shaw, M.C., M.C. Wilson, and C.L. Rhykerd. 1986. Influence of phosphorus and potassium fertilization on damage to alfalfa, Medicago sativa L., by the alfalfa weevil, Hypera postica (Gyllenhall) and potato leafhopper, Empoasca fabae (Harris). Crop Prot. 5:245-249.

Shoup, S.R., R. Reavis, and C. Whitcomb. 1981. Effects of fertilizers and pruning on establishment of barefoot deciduous trees. J. Arboricult. 7: $155-157$.

Schulte, J.R. and C.E. Whitcomb. 1975. Effects of soil amendments and fertilizer levels on the establishment of silver maple. J. Arboricult. 1: 192-195.

Sibley, J.L., D.J. Eakes, C.H. Gilliam, G.J. Keever, W.A. Dozier, Jr., and D.G. Himelrick. 1996. Foliar SPAD-502 meter values, nitrogen levels, and extractable chlorophyll for red maple selections. HortScience 31: 468-470.

Sibley, J.L., J.M. Ruter, and D.J. Eakes. 1998. Differences in growth of container-grown red maple cultivars in different hardiness zones. J. Environ. Hort. 16:130-134.

Sibley, J.L. and J.M. Ruter. 1999. Bark anthocyanin levels differ with location in cultivars of red maple. HortScience 34:137-139.

Smalley, T.J. and C.B. Wood. 1995. Effect of backfill amendment on growth of red maple. J. Arboricult. 21:247-249.

Still, S.M., C.H. Gilliam, and M.E. Watson. 1981. Effects of nitrogen fertilization on Acer rubrum 'Red Sunset' grown in containers. Res. Circ. Ohio Agr. Res. Dev. Ctr. 263:14-16.

Townsend,A.M. 1989. Evaluation of potato leafhopper injury among Acer rubrum progenies. J. Environ. Hort. 7:50-52.

Townsend, A.M. and M.S. McIntosh. 1993. Variation among full-sib progenies of red maple in growth, autumn leaf color, and leafhopper injury. J. Environ. Hort. 11:72-75.

U.S. Dept. of Commerce. 1988. Census of horticultural specialities. In: Census of agriculture. AC87-HOR-1, vol. 4.99.

Van de Werken, H. 1981. Fertilization and other factors enhancing the growth rate of young shade trees. J. Arboricult. 7:191-194.

Vough, L.R., W.O. Lamp, G.R. Nielsen, and A.P. Grybauskas. 1992. Relationships of soil fertility and potato leafhopper incidence to alfalfa yields. Proc. Forage Grassl. Conf. 1:125-130. 